\title{
Perspectives of Existing Storm Water Drainage in Pokhara
}

\author{
Er. Kishor Kumar Shrestha \\ Department of Civil and Geomatics Engineering \\ IoE, Pashchimanchal Campus, T.U., Nepal \\ CorrespondingE-mail: kishor103@wrc.edu.np
}

\begin{abstract}
Addressing issues of waste water is one of the key challenges in the context of Nepal. Being in the highest rainfall area, storm water management is even more crucial in Pokhara. Storm water drains were designed and constructed in Pokhara about two decades ago. Total 50 kilometer long storm water drains have been built which covers the core city area of Pokhara. The design considerations were based on the then available references. Much has been changed since that time and the present data will give different drain cross sections. Further, the concept of discharging storm water in to water bodies without making any pollution need to be reviewed in terms of quality aspects. Review of quantitative as well as qualitative features of the storm water drains could enhance its function more effectively.
\end{abstract}

Keywords: Storm water, Pokhara Metropolitan City (PMC), National Building Code (NBC)

\section{Introduction}

Rapid urbanization has raised numerous issues in cities of Nepal. Infrastructure development could be key issue to be addressed in this context. With population growth, demand for housing and commercial amenities will also grow. Again, the urbanization adds up roads, rooftops, parking lots, sidewalks, and other imperviousness to the landscape. These lead to covering of excessive land surface, thereby preventing rain water to percolate into the ground. In such scenario, most developed areas rely on storm drains to carry large amounts of runoff from roofs and paved areas to nearby water bodies (Bajracharya, Rai and Rana, 2015). Pokhara is the largest metropolitan city in Nepal with 464.24 Square Kilometers area (http:// www.pokharamun.gov.np/) facing challenges in infrastructure development. With excessive increase in population, the burden on physical facilities including drainage is getting crucial day by day in Pokhara. Storm water drainage project was initiated in 1999/2000 A.D. at core areas of Pokhara through Pokhara Environment Improvement Project (PEIP). The Asian Development Bank (ADB) financially supported to the then Pokhara Sub-metropolitan City (PSM) through Tourism Infrastructure Development Program of Nepal. Detailed engineering design and construction of road side drains for storm water under Drainage Improvement Component was complete 
(Shrestha, 2000). It has been 20 years since the construction of the drainage system. This article is mainly focused about issues regarding design of existing storm water drain and its quality management in Pokhara. The packages for storm water drainage construction in Pokhara were as follows.

Table 1: Details of Contract Package and Areas

Covered by Storm Water Drains in Pokhara

\begin{tabular}{|c|c|c|c|}
\hline S. No. & Contract Package No. & Details of Packages & Length (KM) \\
\hline 1 & I & $\begin{array}{c}\text { Miruwa Chowk - INF office and Bagar - } \\
\text { Taxi Chowk to P.N. Campus }\end{array}$ & 1.687 \\
\hline 2 & II & $\begin{array}{c}\text { P.N. Campus - Nadipur Chowk - Palikhe } \\
\text { Chowk }\end{array}$ & 0.748 \\
\hline 3 & III & $\begin{array}{c}\text { Mahendra Pool - Tax Office - Prithvi } \\
\text { Chowk - Pokhara Bus Park, } \\
\text { Prithvi Chowk - Sabhagriha Chowk - BP } \\
\text { Chowk and Chipledhunga Area }\end{array}$ & 8.046 \\
\hline 4 & IV & $\begin{array}{c}\text { Prithvi Chowk - Airport - Mustang Chowk } \\
\text { - Birauta Chowk - Devi's Fall }\end{array}$ & 7.520 \\
\hline 5 & V & $\begin{array}{c}\text { Sabhagriha Chowk - Srijana Chowk - Firke } \\
- \text { Zero KM - Bulaudi - Mansbar - Hallane } \\
\text { Chowk }\end{array}$ & 6.154 \\
\hline 6 & VI & Mahendra Pool - Bhadrakali-Kahun Khola & 6.010 \\
\hline 7 & VII & $\begin{array}{c}\text { Hallane Chowk - Tal Barahi - District Court } \\
\text { - Firke Khola and Gandaki Boarding School } \\
- \text { Engineering Campus - Guhe Kholsi }\end{array}$ & 9.100 \\
\hline & \multicolumn{3}{|c|}{ (Source: Shrestha, 2000) } \\
\hline
\end{tabular}

\section{Study Area}

Pokhara Metropolitan City (PMC) is a rapidly growing city with a population of 402, 995 . The metropolitan city has a population density of 891.6 per $\mathrm{km}^{2}$ (www.pokharamun.gov.np, https://ne.wikipedia.org/wiki).

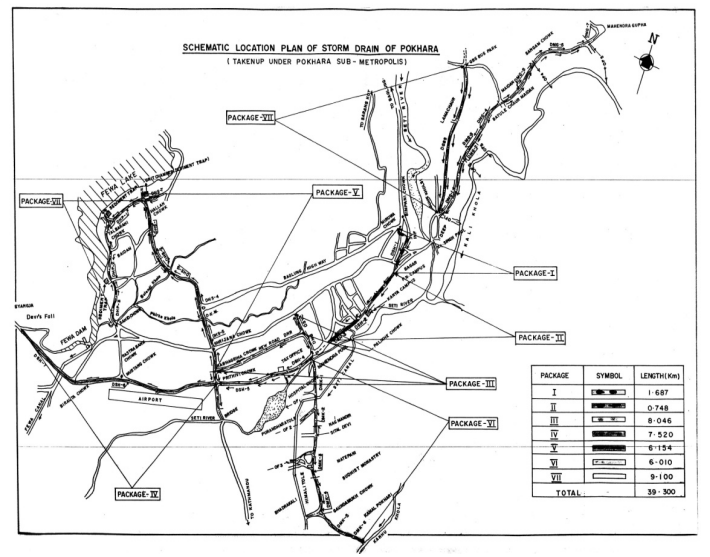

Figure 1: Existing Storm Water Drainage Area (Source: Shrestha, 2000)
The city stands at an elevation of approximately 827 to 1740 meters (https://www.citypopulation. $\mathrm{de} / \mathrm{php} /$ nepal) almost in the central part of Gandaki Province of Nepal.

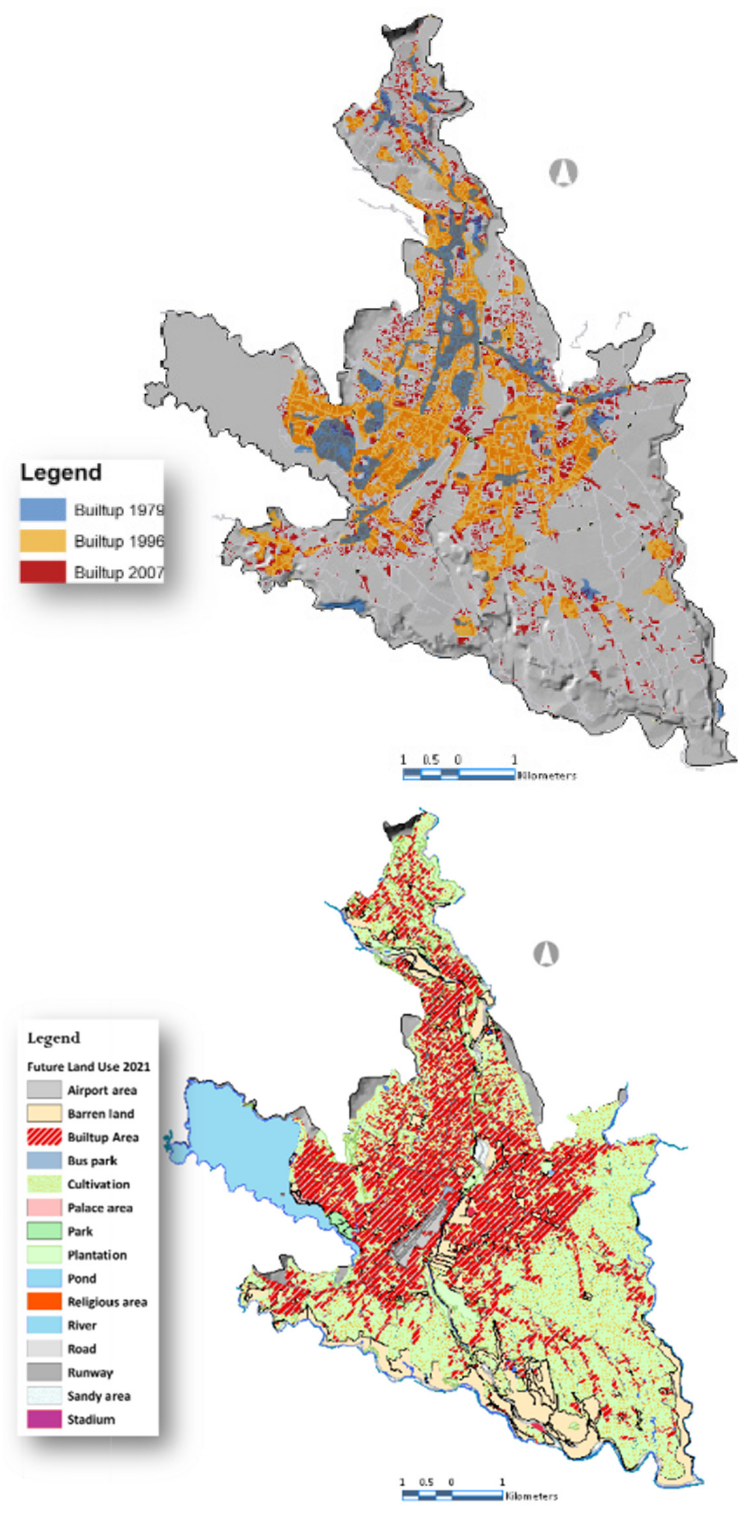

Figure 2: Change in Built up Area from 1979 to 2007 A.D. and Future (2021 A.D.) Land Use Map of Former Pokhara Sub-metropolitan City (Source: Pokhara Sub-metropolitan City, 2010) 
Currently, Pokhara Metropolitan City is having a higher population growth $(5.46 \%)$ rate and as a result, open spaces along with agricultural lands have been converted to built-up area. Such condition has promoted enough issues including rapid runoff. Though few initiations have been taken towards addressing this environmental concern, a lot has to be done.
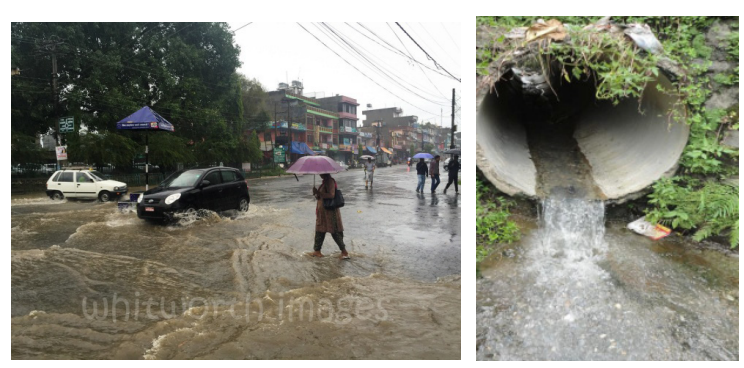

Figure 3: Overflow of Storm Water at Main

Street in Pokhara (a), Storm Water Drain

Outfall (b) (Source: https://hiveminer.com/

Tags/cityCkaski (a), Chand et al., 2015 (b))

\section{Materials and Methods}

For study of previous data and information regarding the existing storm water management, available documents were analyzed. Seminar paper on storm water drainage, project study reports on waste water management in Pokhara along with concerned documents from the Pokhara Metropolitan City were also consulted. Similarly, information/data from related research articles as well as websites were also followed.

Result of above mentioned lab tests was considered as the reference for the design of storm drain in Pokhara (Chand et al., 2015).
Table 2: Storm Water Quality Testing Parameters and Methods

\begin{tabular}{ccc}
\hline S. No. & Test parameter & Testing Method/Instrument \\
\hline 1 & $\mathrm{pH}$ & Universal Indicator \\
2 & Ammonia & ENPHO Kit \\
3 & Dissolved Oxygen (DO) & Titration \\
4 & Coliform P/A & ENPHO Kit \\
5 & Biochemical Oxygen Demand & Titration \\
6 & Escherichia coli (E- coli) & Membrane Filtration \\
\hline \multicolumn{3}{c}{ (Source: Chand et al., 2015) }
\end{tabular}

\section{Results and Discussions}

Various parameters regarding the design and implementation of storm water drains as well as their qualitative aspects could be important while discussing about the existing management of storm water in Pokhara.

\subsection{Design Aspects}

The major basis during the design of storm water drains were a. Hydrological analysis, b. Intensity of rainfall, c. Time of concentration and d. Peak flow estimation. These key parameters of these parts might need to be analyzed in present condition.

Table 3: Main Design Considerations for Storm Water Drain in Pokhara with Possible Update

\begin{tabular}{|c|c|c|c|c|c|}
\hline S. No. & Description & $\begin{array}{c}\text { Considered } \\
\text { Value }\end{array}$ & $\begin{array}{c}\text { Possible Revision } \\
\text { Value }\end{array}$ & Unit & Source \\
\hline 1. & $\begin{array}{l}\text { Average } \\
\text { Annual Rainfall }\end{array}$ & 3830 & 3951 & Millimeter & CBS (2019) \\
\hline 2. & $\begin{array}{l}\text { Return Period } \\
\text { maximum rainfall }\end{array}$ & 2 & $\begin{array}{c}5-10 \\
\text { (up to } 100 \text { Hectares) } \\
25-50 \\
(>100 \text { Hectares) }\end{array}$ & Year & Ponce (2016) \\
\hline 3. & $\begin{array}{l}\text { Intensity of } \\
\text { Rainfall }\end{array}$ & 152 & 148.76 & $\begin{array}{l}\text { Millimeter } \\
\text { per hour }\end{array}$ & $\begin{array}{l}\text { Shrestha } \\
(2000)\end{array}$ \\
\hline 4. & $\begin{array}{l}\text { Maximum } \\
\text { velocity of } \\
\text { storm water }\end{array}$ & $5-6$ & $0.75-2.4$ & $\begin{array}{l}\text { Meter } \\
\text { per second }\end{array}$ & NBC 208 (2003) \\
\hline 5. & $\begin{array}{l}\text { Coefficient of } \\
\text { Runoff }\end{array}$ & $0.1-0.3$ & $0.5-0.95$ & - & NBC 208 (2003) \\
\hline
\end{tabular}

The considered average annual rainfall was based upon rainfall data of Pokhara Airport for year 1971 to 1994 A.D. Out of $3830 \mathrm{~mm}, 80 \%$ of annual precipitation was considered to be during monsoon period, i.e. June to September (Design Report, 2000). However, latest 
available data from CBS (2019) has mentioned the average annual rainfall of $3898.71 \mathrm{~mm}$ for period of year 1980-2010 with $3118.67 \mathrm{~mm}$ during monsoon period. Similarly, the annual rainfall data of $3743.3 \mathrm{~mm}$ was recorded in year 2017 A.D.as well (CBS, 2019).

On the other hand, the return period of 2 years was considered for calculation of rainfall intensity. As per Ponce (2016), its value shall be considered as 5 to 10 years for catchment area up to 100 hectares and $25-50$ years for catchment area greater than 100 hectares. In this case, most of the sections having catchment area greater than 100 hectares, the corresponding change in return period for calculation of rainfall intensity could be important to incorporate while designing the storm water drainage system.

Again, the intensity of rainfall considered while calculating the discharge of the storm water could be revised with due consideration of return period as well as time of concentration. While considering time of concentration as 5 minutes and return period of 50 years, the intensity of rainfall value could be obtained as $148.67 \mathrm{~mm} /$ $\mathrm{hr}$ with following expression used in design (Pokhara Sub-metropolitan City, 2000).

Intensity of Rainfall $(I)=\frac{1380 \times\left(\mathrm{T}^{0.13}\right)}{(\mathrm{tc}+20)^{0.85}}$

Regarding the coefficient of run-off for calculation of storm water discharge, the considered values while calculating the design discharge ranged from $0.1-0.3$. With increase in built up area as well as standard considerations from Nepal National Building Code, appropriate value shall range from 0.5 for general ground to 0.95 for hard paved surface
(NBC 208: 2003). Of course, such variation could be contributing for excessive flow of storm water discharge. Again, considering another storm water design guideline from IOWA, values of runoff coefficient could range from 0.25 to 0.8 for residential areas and 0.25 to 0.95 for streets (IOWA, 2009).

While considering the velocity of flow, maximum velocity up to $5 \mathrm{~m} / \mathrm{s}$ was considered in various sections of storm water drains. However, considerations of $0.75 \mathrm{~m} / \mathrm{s}$ for self cleansing velocity as minimum as well as maximum value of $2.4 \mathrm{~m} / \mathrm{s}$ have been prescribed in Nepal National Building Code (NBC 208, 2003). Lowering the maximum velocity of storm water drain could play very important role for increasing the cross sectional area of the storm water drains. It showed that the corresponding sections designed with excessive velocity value were highly insufficient resulting in overflow (accumulation of storm water) on roads. Though the drain sections were considered fully sufficient during design (Shrestha, 2000), the scenario of streets in Pokhara during monsoon clearly reveal the immediate need of this improper consideration to be rectified further.

\subsection{Quality Aspects}

It is quite essential to discuss about qualitative perspectives of storm water drains in Pokhara. Total thirty three outfalls were planned in the storm water drains including nine to Seti River, six to irrigation canals, three to Fewa Lake and remaining outfalls were to the adjoining streams. During the design as well as implementation of the drain, sewerage connection was strictly 
prohibited. Also, the public comments during design and construction of the drains included the concerns in quality of existing water bodies. Their major view was possible conversion of storm water drains into the sewer lines along with pollution of water in Fewa Lake along with the Seti River as well (Shrestha, 2000).

Table 4: Summary of Laboratory Test Results of Storm Water with Standard Values

\begin{tabular}{rllll}
\hline S. No. & \multicolumn{1}{c}{ Description } & Test Result & Standard Value & \multicolumn{1}{c}{ Unit } \\
\hline 1. & pH & $3.0-8.0$ & $5.5-9.0$ & - \\
2. & $\begin{array}{l}\text { Dissolved } \\
\text { Oxygen (DO) }\end{array}$ & $0.7-4.7$ & 6.0 & Milligram/liter \\
3. & $\begin{array}{l}\text { Biochemical Oxygen } \\
\text { Demand (BOD) }\end{array}$ & $4.2-393.6$ & 25.0 & Milligram/liter \\
4. & Ammonia & $0.0-4.0$ & 1.50 & Milligram/liter \\
\hline
\end{tabular}

During the laboratory testing of major waste water parameters at twelve sections of existing storm water drains, unsatisfactory result was obtained. While comparing such test result of storm water with standard values as an effluent of waste water (Pudasaini, 2008), the major parameters fell out of range indicating significant pollution by the storm water.

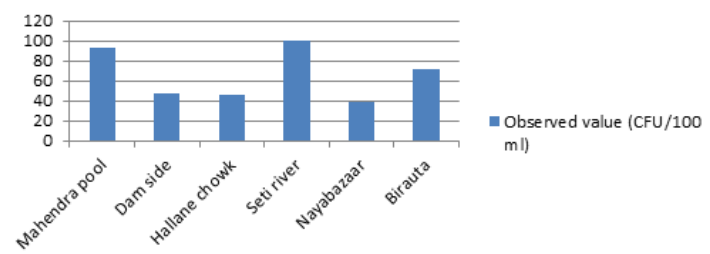

Figure 4: Microbiological Test Report of Waste

Water Samples (Source: Chand et al., 2015)

The physicochemical parameters of storm water samples including dissolved oxygen, $\mathrm{pH}$ values were recorded exceeding the standard limits. Similarly, the average BOD value was also observed excessively higher than the limiting value of the effluent mentioned for disposal. Regarding the microbiological examination, almost all waste water samples were recorded showing presence of the coliform bacteria. 100
Again, the microbiological test report also revealed the significant concentration of Escherichia coli (E-coli) at various outfall points of storm water drains as mentioned in graph above. Obviously, this scenario expressed the mixing of other waste water in the storm water threatening the quality of river, lake as well as streams resembling with concerns of public during design/implementation phase. Of course, the storm water drains could be considered to function as sewer lines based upon the results of quality assessment mentioned above.

\section{Conclusion}

Existing storm water drains in Pokhara were designed on the basis of available hydrological data of two decades. Again, another important parameter, run off coefficient as well as the permissible velocity were also considered based upon available references. In present scenario, the consideration of National Building Code along with recent hydrological data as well as highly changed land use pattern could severely influence excessive storm water discharge demanding changed dimensions of the storm water drains. The quality aspect of the effluent from the drains also critically questioned the revision of concept of storm water disposal into the water bodies including the river and lake. Again, the storm water drainage system shall be promptly reviewed with concept of sewerage system for domestic and other concerned waste water. In spite of deteriorating quality of water bodies, the managing proper infrastructure for the storm water as well as the other waste water could enhance the aesthetic beauty and quality of life in this touristic Pokhara valley including 
the metropolitan area. Yet, another opportunity of using storm water for recharge and reuse after recycling the same is still open.

\section{Limitations}

The analysis was based upon existing storm water drain area in Pokhara which did not cover present wards of the metropolitan city. The laboratory test results were based upon samples from storm water drains at different periods of times with specific numbers. Again, selected parameters were only considered during qualitative examination. Also, the design report as well as selected references was consulted for reviewing the quantitative and qualitative aspects of existing storm water drains.

\section{Acknowledgement}

I would like to show appreciation with thankfulness to Mr. Sabin Chand, Mr. Sudip Dhungana, Ms Tripti Roka and Ms Usha Humagain for their magnificent effort during their final year project work in relevant topic. Regional Water Quality Laboratory, Pokhara under Department of Water Supply and Sewerage is gratified for contribution in microbiological examination of storm water samples. I express my sincere gratitude to Pashchimanchal Campus, Institute of Engineering, Pokhara, for providing laboratory facilities while examination of storm water samples by undergraduate students.

\section{References:}

Bajracharya, A.R., Rai, R.R. and Rana, S. (2015). "Effects of Urbanization on Storm Water Runoff : A Case Study of Kathmandu Metropolitan City", Nepal, A Journal Paper in the Journal of Institute of Engineering, II(I), 36-49, TUTA,
IoE, PCU, Nepal, 2015.

Technical Journal -2019

CBS (2019). "Environmental Statistics of Nepal - 2019", a Publication of Central Bureau of Statistics, Nepal, 2019.

Chand, S., Dhungana, S, Roka, T. and Humagain, U. (2015). "Study of Status of Waste Water Management in Pokhara Sub-metropolitan City", A Final Year Project Report, Bachelor Degree in Civil Engineering, Pashchimanchal Campus, Institute of Engineering, Tribhuvan University, Nepal, 2015.

IOWA (2009). "Storm Water Management Manual"; URL: https://www.iowadnr.gov/ Environmental-Protection/Water-Quality/ NPDES-Storm-Water/Storm-Water-Manual; cited on 25 June, 2019.

Ponce, V.M. (2016). "Question and Answers on the Return Period to be Used for Design" ; https:// www.climsystems.com/docs/simclimdesktop/ GuidelinesforReturnPeriods, cited on 27 June, 2019.

Pokhara Sub-metropolitan City (2010). "A Report on Impact of Settlement Pattern, Land Use Practice and Options in High Risk Areas in Pokhara Sub-metropolitan City", Earthquake Risk Reduction and Recovery Preparedness Programme for Nepal, 2010.

Pokhara Sub-metropolitan City (2000). "Design Report of Storm Water Drains in Pokhara Submetropolitan City", 2056/57, Pokhara, Nepal, 2000.

Pudasaini, K. (2008). "Performance of Wastewater Treatment Plants (BASP and SWTP) In Kathmandu Valley: Case Study of Bagmati Area Sewerage Treatment Plant (BASP) and Sunga Wastewater Treatment Plant (SWTP)", A M.Sc. Thesis, UNESCO-IHE, Institute for Water Education, Delft, Netherlands, 2008.

Shrestha, S. (2000). "Planning and Construction of Storm water Drainage in Pokhara", a presentation in seminar, Pokhara, Nepal, 2000. 